\title{
HAREZMLI TÜRKLERIN ANADOLU VE YAKINDOĞU'DAKİ ROLLERI VE TESIRLERI
}

\author{
MUAMMER GÜL ${ }^{*}$
}

\section{Giriş}

Tarihin en önemli hâdiselerinden biri olan Moğol istilâsı ile Yakındoğu'nun ve Anadolu'nun siyasî, sosyo-kültürel ve etnik-kabilevî yapısında önemli bir değişim meydana gelmiștir. Bu istilâ genel olarak Yakındoğu ve Anadolu açısından bir yıkım getirmesine rağmen, Anadolu' nun güney, batı ve kuzey smırlarındaki uç bölgelerde bir Türkleşme süreci bașlatmıștur ki, bu durum Anadolu'da millî bir dönemin bașlangıcı gibi müsbet bir tesir ortaya koymuștur. Bu durum Doğu ve Güneydoğu Anadolu bölgesi için de geçerli olmaktadır. Zira Moğol istilâsı ile birlikte Anadolu'ya gelen Ak-Koyunlu ve Kara-Koyunlu gibi büyük göçebe Türkmen zümreleri XIV. yüzylldan itibaren bu bölgelerin Türkmeniye olarak adlandırılmasma sebep olacaklardir' ${ }^{1}$.

Bu çalışmamızda Moğol istilâsımm Yakındoğu ve Anadolu'ya sürdüğü Harezmli Türkleri ve onlarmn tesirleri üzerinde duracağız. Moğol istilâsının önünden hükümdarı, devlet teşkilât, askeri ve halkı ile İran, Azerbaycan ve Anadolu'ya gelen Harezmşahlarla birlikte birçok yeni kavmî unsurlar da Anadolu'ya gelmiştir. Selçuklularm hizmetine giren bazı Harezmli emîr ve idarecilerinin yanında, bilhassa Kıpçak ve Kanglı Türklerinin oluşturduğu önemli göçler ile birlikte birtakım derviş zümrelerinin, âlimlerin, varlıklı ve şehirli unsurlarm küçük gruplar hâlinde Anadolu'ya gelerek² Selçuklularm, Eyyubîlerin ve Memlûklarm hizmetine girdikleri bilinmektedir.

• Doç.Dr. Harran Üniversitesi Fen-Edebiyat Fakültesi, Tarih Bölümü Öğretim Üyesi/ Şanlıurfa. Muammergul@mynet.com

' Bu konuda doğu ve bat kaynaklarına dayalı geniş bir değerlendirme için bkz. Tuncer Baykara, Anadolu'nun Tarihi Coğrafyasına Giriş I Anadolu'nun İdari Taksimau, Türk Kültürü Araşurma Enstitüsü, Ankara 1988, s. 145-164; Muammer Gül, "Tarihi ve Coğrafi Bakış Açısından Kürdistan Kavramının Ortadoğu'daki Yeri (Ortaçağlardan Osmanlı Hâkimiyetine Kadar)", Birinci Ortadoğu Semineri (Kaıramlar Kaynaklar ve Metodoloji). Bildiriler, Elazı̆g 2004, s. 87 97.

\footnotetext{
${ }^{2}$ M. Fuad Kōprülü, Türk Edebiyatı Tarihi, Ötüken Yaynevi, İstanbul 1981, s. 241.
} 
Harzemșah Alaaddin Muhammed'in 1220 yllında ölümünden sonra yerine oğlu Celâleddin Harzemșah geçmiștir ${ }^{3}$. Celâleddin, Moğollar ile mücadele ederek, önce Hindistan'a oradan da İran'a geçmiștir. 1224 yllında Kirman'a gelen Celâleddin, burada hükümdar gibi karşılanmıș ve 12241225 yıllarında Abbasî Halifesi en-Nâsır li-Dinillah'ı da yenerek İran'ın batısına hâkim olmuștur'. 1225-1226 yılında Dvîn'de önce Ermenileri ve arkasından da Hıristiyanlığın kuzeydoğudaki karakolu olan Gürcüleri ağır bir yenilgiye uğratarak Kafkasya'nın hâkimi olan Celâleddin'i, Moğollar karșısındaki bașarılanı ile birlikte haklı bir șöhrete kavuştu.

Türkiye Selçukluları ile başlangıçta iyi olan ilişkiler ${ }^{7}$, Celâleddin' in Eyyubîlerin elindeki müstahkem ve zengin Ahlat Kalesi'ni almaya niyetlenmesi ile bozulmuştur. Celâleddin, 1226-1227 yıllarında Ahlat'ı kușatmış, arkasından da Bingöl'e kadar olan bölgeleri yağmalayarak Güneydoğu Anadolu şehirlerine kadar uzanan bir korku ve tesir bırakmışı ${ }^{8}$. Onun sekiz aylık bir kuşatmadan sonra Ahlat'ı 1230 yılında alarak yağmalaması", Yakındoğu'daki dengeleri değiștirdi. Abbasî halifesi el-Mustansır Billah, Celâleddin'e saltanat hil'ati gönderirken, sultan da babası zamannndan beri İran coğrafyasında hutbelerde adı zikredilmeyen halifeye dua edilmesine

3 Şehabeddin Ahmed en-Nesevî, Siret-i Sultan Celâleddin Mengübertî. Çev. Necip Asım. İstanbul 1934, s. 40.

${ }^{4}$ Nesevî, s. 40-60.

${ }^{5}$ Müverrih Vardan, "Türk Fütuhat Tarihi", Çev. H. Andreasyan, Tarih Semineri Dergisi, IÜEFY, İstanbul 1937, s. 224; Alaaddin Ata Melik Cüveynî, Tarih-i Cihangüșa, Cev. Mürsel Öztürk, TCKBY. Ankara 1999. s. 350-351; H.H. Howorth, Moğol Tarili, C. 3, Türkçe tercüme: Saffet Korkut-S.Hikmet Baban. TTK Ktp. Daktilolu tercüme yazmalar. Sayı: 40/62d, s. 3-5; J.A.Boyle, "Djalal-al-Din Kharzemşah", EI, C. 4, London 1980, s. 393; Aydın Taneri, "Celâleddin Hazemşah", DiA, C.7, İstanbul 1993, s. 250.

${ }^{6}$ Genceli Kiragos, Moğol Ístilası Tarihi (1220-1265), Türkçe tercüme: Hrand D. Andreasyan, TTK Ktp. Daktilolu tercüme yazmalar. Sayı: 27, s. 1-5; Nesevî, s. 69 vd.; Cüveynî, s. 354 vd; İbnü'l-Esîr, el-Kamil, C. 12, Cev. A.Ağ rakcça-A.Özaydm, Bahar Yay., Istanbul 1987, s. 394396, 412 vd.; Osman Turan, Selçuklular Zamanında Türkiye, Boğaziçi Yay., İstanbul 1998, s 363; Howorth, s. 8, 17-18; Steven Runciman. Haçlı Seferleri Tarihi 3, Çev. Fikret Ișıltan, TTK. Ankara 1992, s. 214.

7 İbn Bîbî, el-Evâmirü'l Ala'iye fi'l Umûru'l Ala'iye, I, Haz. M. Öztürk, TCKBY, Ankara 1996, C.I, s. 374 vd.; Osman Turan, Türkiye Selçuklulan Hakkunda Resmî Vesikalar, TTK Ankara 1988, s. 82-101.

* İbnŭ'l-Esîr. C.12, s. 422-423, 443-444; Kiragos, s. 8; Howorth, s. 17-19.

" İbn Tagribirdi, Cemaleddin Ebi'l-Mehâsin Yusuf, en-Nücûmu'z-Zâhire fi Mülûk Misu ve'l Kahire, Tahkik: I.Ali Tarhan-M.Mustafa Ziyade, Misır 1392-1972, C. 6, s. 270, 271; Nesevî, s. 107. 124-130; Gregoryus Abu'l-Farac, Tarih-i Muhtasaru'l Düvel, Dar el-Lübnan, Beyrut H. 1403M. 1983, s. 429; İbuü'l-Esîr, C.12, s. 450-451. 
müsaade etti ${ }^{1 /}$. Bu arada Erzurum meliki Cihanşah, Trabzon'daki Rumlar, Diyarbekir, Hısn Keyfa ve Mardin Artukluları da ona tâbiiyetini bildirdiler ${ }^{\prime \prime}$. Nihayet Eyyubîler ile ittifak kuran I. Alaaddin Keykubad, Celâleddin'in ordustunu 1230 yılında Yassıçemen'de bozguna uğratmıştır'².

Celâleddlin, vaklașan Moğol tehlikesinden dolayı bir ittifak teșebbüsüne giriștiyse $^{t 3}$ de Ahlat ve çevresinde yaptığı büyük tahribattan dolayı destek bulamadı. Mugan'da Moğollanm baskımma uğradı" ve Aras'ı geçerek Mahan Ovası'na indi. Moğolların takibinden dolayı Eyyubîlerin yardımını alma ünidi ile Aras-Eleşgirt-Malazgirt-Hani yolu ile Diyarbakır önlerine geldi. Moğollar ise Bargiri-Ahlat yolundan inerek 1231'de Dicle Köprüsü önünde Celâleddin Harezmşah'a ani bir baskın düzenlediler. Celâleddin'in yanındaki birkaç kiși ile kaçı̆̆ı Meyyâfânkîn(Silvan)'m dağlık bir bölgesinde bir çoban tarafından öldürüldü̈ ${ }^{t: 5}$.

\section{1- Celâleddin'den Sonra Harezmli Türklerin Yakındoğu ve Anadolu'- daki Siyasî Rolleri (1231-1246)}

Yassıçemen Savași'ndan somra Doğu Anadolu'da Selçuklular, Güneydoğu Anadolu'da ise Eyyubîler daha kuvvetli bir hâle gelmişlerdi. Daha önce Celâleddin'e karşı ittifak kưan bu iki gụ̈, șimdi bölge üzerinde mücadeleye bașladılar. Bu hâkimiyet mücadelesinin araçlarmndan biri de Celâleddin'in ölümünden somra bașsız kalan ve coğumlığunu Kangl-Kıpçak kabilelerinin teșkil ettiği Harezmliler idi. 1231-1246 yılları arasında Türkiye Selçukluları ile Eyyubîler ve bilhassa Eyyubî melikleri arasındaki mücadelelerde Harezmliler en etkili unsurlardan biri olacaklardır. Onların başsız kalmaları

${ }^{10}$ M. Halil Yinanç, "Celâleddin Harzemșah", IA, C.3, MEB, İstanbul 1988, s. 51.

$"$ Cuvevnî. . s. 368; Howorth, s. 17-19.

12 Cemaleddin Muhammed b. Salim İbn Vâsıl, Müferric el-Kurûb fi Ahbâr-ı Beni Eyñb, Cüz 4. Matbaat-ı Daru'l Kütub 1976, s. 302; en-Nesevî, s. 131-132; Ibn Bibî, I, s. 406 vd; İbnü'lEsir, C. 12, s, 453-154; Abu'l-Farac, Muhtasar, s. 430; O. Turan, SelçukJular Zamammda Türkive. s. $369-374$.

13 Curevili. 5. 371 .

11 Kiragos, s. 9-10.

15 Nesevî, s. 155-158: Gregorv Abu'l-Farac, Abu'l Farac Tarihi, 2, Cev. Ö.Rıza Doğrul, TTK Ankara 1987, s. 529-530; Cüvevni, s. 372-377; Ibn Bibî, I, 394; Ibnü'l-Esir, C.12. s. 461 vd.; Vardan. s. 224: Abu'l-Farac, Muhtasat, s.431: Ibn Vasil, s. 321-322; Kiragos, s. 9-10; Ibn Tagribirdi, C. 6, s. 275-276. 
ve bilhassa yağmacı karakterleri bölgedeki siyasî olaylarda sürekli taraf olmalarma sebep olacaktur.

Celâleddin'in 1231 baharında ölümünden sonra Doğu ve Güneydoğu Anadolu'da Kayı Han'm önderliğindeki dağımı Harezmlilerin bașlangıçta, hiç olmazsa bir iki yıl, Ahlat ve Meyyâfârıkîn Eyyubîlerine bağlı olduğı1"i anlaşılmaktadır. Ancak Keykubad'm, Ahlat ve Tatvan bölgesinde bașıboș dolașıp yolları kesen Harezmlilerin itaate alınması ve Ahlat ile Bitlis'ten Tiflis'e kadar olan bölgelerin fethini istemesinin bir sonucu olarak ${ }^{17}$ Ahlat 1233'te Eyyubîlerden alınmıștır. Böylece Harezmlilerin büyük bir kısmı bașlarında Kayı Han, Bereket Han, Ylan Boğa, Can Birdi, Saru Han, Güçlü Han gibi komutanlar ${ }^{1 *}$ bulunduğu hâlde Selçuklular ile anlaşarak Erzurum'u ikta olarak almışlardır ${ }^{19}$. Türkiye Selçukluları, muhtemel bir Moğol saldırısı karşısında, Doğu ve Güneydoğu Anadolu'da bir taraftan askerî-siyasî tedbirler alırken diğer taraftan Ahlat ve çevresinin ekonomik ve sosyal hayatının yeniden düzenlenmesi ile meșgul olmuşlardır. Bu sebeble bölgeye gönderilen bir heyet ile halk ve toprak sahipleri eski topraklarma davet edilirken onları çiftçilik ve ziraate özendirmek için vergilerde bir süre müsamaha gösterilmiștir ${ }^{20}$. Ancak daha sonra, Moğol baskısı ve endișesinden dolayı, Harezmli komutanlara İ̧̧ Anadolu'da iktalar verilerek güçlerinden istifade yoluna gidilmiștir. Bu amaçla Kayır Han'a Erzincan, Bereket Han'a Amasya, Güçlü Sengüm'e Larende ve Yllan Boğa (Bilen Togu)'ya Niğde ikta olarak verilmiş, oğullanı, adamlanı ve askerlerinin daha sonra kendilerine katulacağ $1^{21}$ zikredilmiștir ki, bu durum onların henüz toparlanamadığımı göstermektedir.

${ }^{\prime \prime}$ Claude Cahen, Osmanlılardan Önce Anadolu'da Türkler Cev. Yıldız Moran, E Yaynlan. İstanbul 1994, s. 139.

17 İbn Bîbî, I, s. 426, 429.

18 Türkiye Selçuklularının hizmetine giren bu Harezmli komutanların isimleri kaynaklarda farklı şekillerde geçmektedir. Bunlar Kayır Han=Gayır Han, Berke Han=Bereket Han=Barka Han, Can Birdi=Han Birdi, Güçlü Han=Küçlü Han=Küşlü Han=Güçlü Sengüm, Yılan Boğa=Bilen Toga gibi genellikle Arap harflerinin farklı okunuşlarından kaynaklanmaktadır.

19 İbn Bîbi, I, 430-432; O.Turan, Selçuklular Zamanında Türkive, s. 377-378.

20 İbn Bỉbî, 1, 426-427; Erdoğan Merçil, Türkiye Selçuklularında Meslekler, TTK, Ankara 2000, s. 47: O. Turan, Selçuklular Zamammda Türkiye, s. 337.

21 İbn Bîbi, I, 431-434. 
Alaaddin Keykubat döneminde Selçukluların hizmetine giren Harezmliler'in bazı kaynaklarda 10.000 kişi oldukları zikredilirken ${ }^{22}$ bazı kaynaklarda ise çevreye dağılanların dışında ve sadece Ahlat bölgesinde 12.000 kişi oldukları zikredilmektedir ${ }^{23}$. Harezmlilerin, Selçukluların itaatinden çıktıktan sonra Suriye'deki büyük istila hareketi sırasında yukarıda zikredilen liderlerinin emrinde 10.000 atl olarak zikredilmesi ${ }^{24} \mathrm{de}$, Doğu ve İç Anadolu ile Güneydoğu Anadolu'da kalanlar ile kendilerine sonradan katılanlar dikkate alındığında, sayılarının bu rakamlardan az olmayacağı açıktur. Bunların Selçukluların hizmetinden çıktıktan sonra Eyyubîlerin hizmetine girdikleri zaman sayılarının 20.000 kişilik kuvvete ulaștuğı görüşü de bu açıdan önemlidir ${ }^{25}$. Keykubad'm hizmetine giren bu Harezmlilerin sayısı hakkında her hâlde beş-altı bin atlıdan ibaretti ${ }^{26}$ değerlendirmesi yukarıda adı geçen beylerin doğrudan emrinde olan Harezmlilerin Anadolu'daki çekirdek kuvvetleri için doğru olmalıdır. Zira İbn Bîbî'nin Erzurum baskını sırasında "dört bin Harezmli ile yedi yüz Moğol" hikâyesi ${ }^{27}$ de Harezmlilerin henüz toparlanmadığı gibi kendilerine daha sonraki katılımların da hesaba alınmadığını göstermektedir. Aynca Harezmlilerin Selçukluların itaatinden çıtıktan sonra el-Cezire ve Kuzey Suriye'deki yağmalar sırasında kendilerine gerek bu bölgede Duduoğlu'nun başında bulunduğu Türkmenler ${ }^{28}$ ve gerekse Şiraz'dan Celâleddin'in yeğeni Yağan Tayși önderliğindeki katılımlar": ile daha da güçlendikleri anlaşılmaktadır. Selçuklu hizmetinden çıkan Harezmlileri tekrar devlete bağlamak için sahip olduklan yerlerin tanınması şart kabul edildikten sonra Selçuklulara "Suriye, Şiraz, Misır ve Hicaz'dan katılmış olan, bazısı sultanın topraklarında bazısı başka yerlerde yaşayan askerlerimiz sizi sıkmtıya sokacak bir harekete girmeyecekler" ${ }^{{ }^{30}}$ şeklinde

${ }^{22}$ Abu'l-Farac, Ebu'l Farac Tarihi, 2, 530.

23 İbn Vâsıl, s. 325; O.Turan, Selçuklular Zamanında Türkiye, s. 378; Osman Turan. “Keykubad I", IA, C.6, MEB, İstanbul 1988, s. 656.

21 İbn el-Furat, Tarikh al-Duwal wa'l Mülûk, Volum 1; The Text, M.C. Lyons, Cambridge 1971 , s. 386.

${ }^{25}$ Osman Turan, Doğu Anadolu Türk Devletleri Tarihi. Turan Neşriyat Yurdu Yay., Istanbul 1973, s. 182.

5.

${ }^{26}$ Faruk Sümer, "Anadolu'da Moğollar, "Selçuklu Araşturmalanı Dergisi" I, Ankara 1970, s.

${ }^{27}$ İbn Bîbî, I, 432.

${ }^{2 \mathrm{~K}}$ Faruk Sümer, Oğuzlar (Türkmenler), Tarihleri-Boy Teşkilatı-Destanları, Ana Yayınları, İstanbul 1980, s. 598-599.

2!) İ̉nn Bîbî, 2, 55.

30 İbn Bîbî, 2, 40. 
vaatte bulummaları da dağılan Harezmşahlar Devleti'nin bakiyelerinin yukanda zikrettiğimiz gibi Suriye, Musul, Acem ve Hint'e kadar çok genis bir coğrafyaya dağılmıs oldıklan ve bir kısmının da hâlâ Selçuklu topraklarında oldukların göstermektedir. Dağınk ama birbirlerine bağlı, kolayca toparlandıkları gibi kolayca dağılabilen Harezmli Türklerin bu hareketlilikleri, onların hem gücünü hem zaafını teşkil ediyordu. Zaten Suriye istilâsı sırasında o kadar çok bâdire atlatmalarına rağmen sayılaıının 10.000 athı çıkaracak kadar artması da bunu göstermektedir. Ayrıca Baba İshak isyanı surasında, isyan ile ilişkileri ne olursa olsun, bölgenin önemli bir gücü olarak kendilerine başvurulması da bu durumlarım açıklamaktadır.

Keykubad, Harezmlilere büyük bir itibar gösterdiği gibi onlara ülkenin en fazla geliı getiren vilâyetlerinden bazılarını ikta olarak vermişti. Kayır Han başta olmak üzere diğer Harezmli emîrler, Eyyubîler'in Anadolu harekâtı karşısında, Keykubat'm emrinde harekete geçtikleri gibi Selçuklu ordusunun 1236'daki Diyarbakır muhasarasına da katılmışlar ve o bölgede büyük tahribat yapmışlardı ${ }^{31}$. Ancak bu seferin sonuçsuz kalması üzerine sultanın yeni bir sefer için ordusunu Kayseri'de topladığında, Harezmlilerin en önemli komutan Kayır Han'a Sivas işlerinin çekilip çevrilmesi ve orann korumması görevini vermesi" ${ }^{2}$, Keykubad'm hem onlara olan güvenini hem de Harezmlilerin devlet içindeki konumlarm ortaya koyuyordu. Harezmlilere iktalarında ne oranda yetki tanındığı bilinmemektedir, ama onlara tam yetki verilmediği söylenilse de ${ }^{33}$ önemli şehirlerin ikta olarak verilmesi, askerî seferlerdeki rolleri ve en son Sivas gibi bir șehrin valiliğinin Kayı Han'a verilmesi, merkeziyetçi bir idareye eğilimli Türkiye Selçuklular için özel bir durumun oluştuğu anlașılmaktadır.

Gerçekten Keykubad'ın Harezmlilere devlet içinde önemli bir yer vermiș olması, onların çeșitli rakipleriyle işbirliği yapmalarmı önlemek ve onların savaș̣ı özelliklerinden yaklaşmakta olan Moğol tehlikesi karşısında yararlanmayı düșinmmesiyle alakalı olduğu gibi" ${ }^{3}$, Keykubad'm bu taze Harezm unsurlarmı tercih ederek, bir ıslah hareketine başladığı da sezilmekte ve hatta ölümünün bile bu teșebbüsü ile alâkalı oldığuna dair bazı alâmetler 290.

"3 İbn Bîbî, I, s. 435-447; Fuat Köprülü, "Harezmşahlar", IA, C.4, MEB, İstanbul 1988, s.

3² Ibn Bîbî, I. s. 454-455.

33 C. Cahen, Osmanhlardan Önce Anadolu'da Türkler, s. 242-243.

" C. Cahen, "The Turks in Iran and Anatolia Before The Mongol Invasion", A History of The Crusades, University of Pennsvliana Press, Pliladelphia, s. 673. 
olduğu zikredilmektedir ${ }^{35}$. Onun ölümünden hemen sonra ona yakın devlet adamlan ile Harezmlilerin en güçlü komutanı Kayır Han'ın tasfiye edilmesi bu açıdan dikkat çekicidir. Bazı kaynaklarda Deylemli olduğu zikredilen ${ }^{36 i}$ Anadolu Selçuklu Devleti'nin veziri Saadeddin Köpek'in iftirası ile ilk önce Harezmlilerin en büyük emîri olan Kayır Han tutuklanmıș ve arkasından da hapsedildiği Zamantı Kalesi'nde 1237 yılında ölmüștü. Durumu öğrenen diğer Harezm emîleri ve askerleri Selçuklu topraklarından çıkmak için süratle hareket ettiler ve geçtikleri yerleri tahrip ettiler. Sultan, onların geri döndürülmeleri için harekete geçmesine rağmen onlar, Malatya bölgesinde Fırat'ı geçtiler ve burada Selçuklu kuwetlerini yenerek elde ettikleri önemli ganimet ile Harran, Urfa, Rakka, Suruç ve çevredeki beldeleri ele geçirerek oralara malikhane hükmüne göre sahip oldular ${ }^{37}$.

Burada dikkate alınması gereken birinci husus, Selçuklu idaresinin bu tutumunun sadece Kayır Han'in șahsına değil, Harezmlilere karșı genel bir bakıșı yansıttuğı ve Harezmlilerin de bunu kendilerine karşı bir tavir olarak anlamış olmalaıdır. Harezmlilerin bir kısmı Selçuklı topraklarında kalıış ise de toplu olarak harekete geçmeleri de bunu işaret etmektedir. İkinci husus ise, Harezmlilerin toplu bir şekilde İç Anadolu'dan Selçuklu sınırları dıșındaki Güneydoğu Anadolu'ya yönelmeleri sadece Selçuklu idaresinden kaynaklanmıyordu. Harezmliler büyük çoğunlukla 'göçebelik' karakteri ağır basan Kanglı-Kıpçak boylarına dayanıyordu. Cüveynî, onların tabiatı hakkında șu bilgileri vermektedir:"Bunlar nereye gitseler oray harap ederler, halk onları gördügü zaman kaçacak delik aradı. Onların halka reva gördüğü eziyet ve zulüm sultanun devletinin temellerini sarsan en önemli etkenlerden biridir" ${ }^{\prime \prime 3}$. Gerçekten de Harezmlilerin bu tabiatımı bütün tarihleri boyunca gözlemlemek mümkündür. Onların Yakındoğu'da Moğolların habercisi olması, sadece Moğolların sürekli takibine uğradıklarından dolayı Moğol istilâsının olduğu bölgelerde ilk olarak onların görünmeleri ile değil, fakat aynı zamanda İslâm âlemindeki Moğol tahribatının adeta provasımı

35 Alaaddin Keykubad'ın Selçuklu yüksek idare mevki ve muhitindeki acemleşme ve manevi sükutu görerek bu taze Harezmli unsurlarm bir sslah için onun tarafindan ön plana çıkarıldığı söylenmektedir. Bkz. O. Turan, "Keyhüsrev II," IA. C.6, MEB, İstanbul 1988, s. 626.

36 el-Aynî, Ikd al-Cuman fí Tarih ehl iz-Zaman, C. 2, Nşr. M. Muhammed Emin, Kahire 1987, s. 165.

${ }^{37}$ İbn Bîbî. 2, 23-24; Abu'l-Farac, Ebu'l Farac Tarihi, 2, 537; Abu'l-Farac, Muhtasar, s. 437438; Ibn Tagribirdi, C. 6, s. 297-323.

${ }^{38}$ Cüveynî, s. 381. 
yapmaları ile alâkalıdır. İbn Bîbî, onlar için " $O$ Yabguluların halefleri, tüccarları ve ziraat yapanları yağmalıyorlardı" demektedir ki, burada XI. yüzyıldaki Yabgulı Türkmenlerinin de bölgede benzer bir tesir bıraktıkları anlaşılmaktadır. Aynı șekilde İbn Vâsıl, Harezmliler Müslümanlarm canlarına ve haremlerine Karamatî" hariç kafirlerin yapamayacağı kötülükleri yaptular ${ }^{10}$ diyerek Harezmlilerin Anadolu, Suriye ve Filistin bölgelerinde meydana getirdikleri büyük yağma ve tahribatın boyutlarını bize göstermektedir. Harezmliler Suriye ve Filistin bölgesinde sultanları ve emîrleri haraca bağlayan İsmailîlerin merkezlerini bile yağmaladıkları anlaşılmaktadır"l.

Kendilerine İç Anadolı'da ikta olarak verilen topraklarda serbest hareket edemeyen Harezınliler (İç Anadolu, yerleșik şehirli yapısı ve devletin merkez alanını oluşturması açısından onlara pek uygun değildi.), belki de Kayır Han olayın bahane ederek buradan Güneydoğu Anadolu bölgesine gelmişlerdir. Burada adı geçen șehirlerde "malikhane hükmüne uydular" 12 şeklindeki kayıt, arazinin hiçbir devlete tâbi olmaması mânasına gelmektedir $^{43}$. Bu durum onların İç Anadolu'daki iktalarında böyle geniş yetkilere sahip olmadıklarını gösterdiği gibi bu hareketlerinin anlaşılmasımı da kolaylaşturmaktadır. Üçüncü husus ise, Selçuklular için ilk sarsıntı ve devlet bünyesinde açılan ilk yara olması ile hareketin Türkiye Selçukluları'nın iç dengelerini etkilemesidir. Harran, Urfa, Musul, Re'sülayn beldeleri ile bağlı yerleri ele geçiren Harezmliler, buralan kendi aralarında paylaşmışlar, baskın ve yağmalar ile bölgedeki Eyyubî meliklerini haraca bağlamıșlar ve giderek güçlenmişlerdir."

3!' İbn Bîbî, 2, 39.

* Karmatîlik, 890 yılında Vasıt bölgesinde Hamdan Karmat'un isyan ile bașlayan ve IX.XII. Yüzyıllar arasında İslâm âlemini sarsan dinî, siyasî, sosyal, iktisadî yönleriyle bilhassa Ahsa. Horasan, Suriye ve Yemen'de etkili olmuş bir harekettir. Bu hareket İslâm âleminde Abbasi dỏnemi ile başlayan hızlı nüfus artıșı ve ona paralel hızh şehirleșmenin getirdiği toplumsal hareketlilik ve ortaya çıkan yeni sosyal tabakalașma tablosu içinde daha çok toplumsal alt tabakalar ile kóy ve kasabalardaki kırsal kesim ve bedevîlere dayanan bir hareket olmuştur. Genel bir tablo için bakz. L.Massignon, "Karmatîler", I.A, C.6, s. 352-359.

"' İ bn Vâsıl, s.285.

"İ̉n Vâsıl, s. 290.

${ }^{12}$ İbn Bîbî, 2, 24.

${ }^{13}$ O.Turan, Resmi Vesikalar, 33.

"I Íbn Bîbî, 2, 39; Kazım Paydaș. "Moğol İstilasından Sonra Urfa ve Harran'a Yerleșen Harezmliler". Türk Dünyası Araşturmaları, Sayı 150, Haziran 2004, s. 158-160. 
Kayır Han'dan sonra bașlarına Bereket Han'ın geçtiğini tahmin ettiğimiz Harezmlilerin ${ }^{15}$ buradaki konumlanı da dikkate şayandır. el-Cezîre hâkimi el-Melik es-Salih Necmettin şehirlerinin Harezmliler tarafindan istilâsı karșısında bir șey yapamamış ve onlardan faydalanmayı akıllıca bir yol olarak görmüștür ${ }^{46}$. Böylece yerleştikleri bu beldelerde, 1237 yılından 1246 yılında askerî ve siyasî olarak varlıklarına son verilinceye kadar, el-Cezîre-Suriye-Filistin hâdiselerinde önemli rol oynamışlardır. Bu süre içerisinde Harezmlilerin lideri konumunda olan emîr ise bölgenin en güçlü kalesi Harran'da oturan Muhammed Berke Han b. Devletşah idi. Berke Han, el-Melik es-Salih'in kız kardeșini alarak Eyyubîler ile akrabalık kurmuş ve Celâlettin' in münșisi Muhammed Nesevî'yi kendisine vezir yapmıștur ${ }^{17}$. Ancak onların bu bölgedeki kervanları soyma ve yağma hareketleri ile artan şikâyetler Selçukluları harekete geçirdi. Selçuklu sultanının davet girișimi kısa bir süre için de olsa anlaşma ile sonuçlanmıștur. Buna göre Harezmliler, sahip oldukları beldelere saltanat menșûru ve ikta yolu ile sahip olmușlardır. Bunun karşılığında kendilerine Suriye, Şiraz, Mısır ve Hicaz'dan katılmıș olan ve bazısı sultanın topraklarında, bazısı başka yerlerde yaşayan askerlerinin sultanı sıkıntıya sokmayacakları șeklinde söz vermişlerdir. Buna rağmen Harezmliler ancak kısa bir süre sözlerinde durup tekrar yağma yapmışlardır ${ }^{48}$.

Harezmlilerin Güneydoğu Anadolu ve Suriye olaylarında etkili olmalarının bir göstergesi de Babaî İsyanı ile olan ilișkileridir. Baba İshak'ın Harran ve Urfa bölgelerine hâkim olan Harezmlilere davetçiler göndermesi ve onlara II. Keyhusrev'i kötülemesi, isyanda Harezm Türklerinin kışkırtmaların ${ }^{49}$ akla getirmektedir. Harezmlilerin bu isyana iștirak ettiklerini gösteren bunun dișında henüz bir delil olmamakla beraber, onların sultanla yeni anlaşmaya vardıklanı göz önüne alınırsa, buradaki karşılıklı durumları

${ }^{5}$ İ İn Vâsıl, s.135.

46 İbn Tagribirdi, C. 6, s. 297; M.C.ȘehabeddinTekindağ, "Al-Malik As-Salih", IA, C.7. MEB, İstanbul 1989, s. 674; M.C.Şehabeddin Tekindağ, "Memlûk Sultanlığı Tarihine Toplu Bir Bakıș", İstanbul Üniversitesi Edebiyat Fakültesi Tarih Dergisi, S.25, Mart 1971, s.5.

${ }^{47}$ İbn Bîbî. 2. 42-43; M.F. Köprülü, "Harizmşahlar", s. 291; Ramazan Șeșen. Harran Tarihi, Ankara 1996, s. 25-26. İbn Bibi, Muhammed Nesevi'den Şihabeddin Zenderî olarak bahseder.

48 İbn Bîbî, I, s. 39-40.

49 İbn Bîbî, 2, s. 60; Ahmet Y. Ocak, Babaîler İsyanı, Dergah Yay., İstanbul 1980, s. 76-77; M.F. Köprülü, Osmanh Imparatorluğunun Kuruluşu, Ötüken, İstanbul 1981, s. 98; F. BabingerFuat Köprülü, Anadolu'da İslamiyet, Çev. R.Hulusi-Yayına Haz. M.Kanar, İnsan Yay., İsatnbul 1996, s. 51-52; F. Sümer, "Anadolu'da Moğollar," s. 8; Abdulbaki Gölpınarlı, Mevlana Celaleddin, İnkalap Kitabevi, İstanbul 1985, s. 6. 
daha iyi anlaşılır. İsyanda Harezmlilerin yanında Eyyubî melikleri ile Moğollarmn kıșkırtmasınm olabileceğ $\mathrm{i}^{\mathrm{th}}$ zikrediliyorsa da Eyyubî meliklerinin bu surada göçebe karakterli Harezmlilerle bașı yeterince dertte olduğu ve Selçuklu sultanmmn yardımma muhtaç oldukları için bu mümkün görünmemektedir. Ayrica hem bu hâdisenin, hem de Harezmlilerin konumunun anlașılması açısından dikkat edilmesi gereken bir husus da, XIII. yüzyıl bașından itibaren Moğol istilâsının bir sonucu olarak, Doğu ve Güneydoğu Anadolu ve Suriye'de göçebe kitlelerinin yoğunlaşması ve siyasal ağırlık merkezinin onların lehine değișmesidir. Bu durum XV. yüzyıl bașlarma kadar sürecektir ki bölgede Ak-Koyunlu ve Kara-Koyunlu göçebe Türkmen devletleri böyle bir zemin üzerinde kurulmuștur. Baba İshak İsyanı'nı da Harezmlilerin rollerini de ancak bu göçebe ve göçebelik sosyal taban üzerinde izah edebiliriz. Göçebe karakterindeki aşiretlerin yağma ve baskmnla ganimet elde etmeleri Babaî gücünün kaynağı olduğu gibi Harezmlilerin Selçukluların hizmetinden çıtıktan sonraki güçlenmesi ve sürekli uzak bölgelerden katılım olması temelde bu yapı ile ilgilidir. İbn Bîbî, onların bu dönemde giderek güçlendikleri, Şiraz'dan, Kirman'dan, Suriye'den, Hicaz'dan, Misır'dan, Anadolu'dan katılım olduğunu zikretmektedir ${ }^{51}$. Yine 1241-1242 yllnda 70.000'i piyade ve bir kısmı süvari olmak üzere Duduoğlu kumandasında büyük bir Türkmen kuvvetinin Harezmliler'e iltihak etmesi $^{\text {t22}}$ de bașka türlü izah edilemez.

Harezmlilerin el-Cezire ve Kuzey Suriye'de soygun ve yağmada bulunmaları ve 1240 yllunda Halep kuvvetlerini mağlup etmeleri ${ }^{53}$ üzerine Suriye Eyyubî melikleri Selçuklu sultanından aldıklanı kuvvetle 1240'da Re'sülayn'da onları bozguna uğrattular. Bu durum onların Urfa ve çevresinden çekilmesine ve bir kısmmm Berke ve Güçlü Han liderliğinde Bağdat'a sığımmasma sebep olmuştur ki Halife el-Mustansır Billah onları himayesine almıștır'. Bereket Han'ın vezirliğini yapan ve Harran Kalesi'ne hâkim olan Muhammed Nesevî ise Selçuklu sultanma bağlanmak istemiș,

${ }^{50}$ M.F. Köprülü, Osmanlı İmparatorluğunun Kuruluşu, s. 98; A.Y. Ocak, s. 76.

51 İbn Bîbî, 2, s. 39-40.

52 M.F. Kòprülü, Osmanlı İmparatorluğınun Kurulușu, s. 98; F. Sümer,Oğuzlar, s. 598 599.

53 İbn Şeddad, Baypars Tarihi. Türkçeye çev. Șerefüddin Yaltkaya,TTK, Ankara 2000, s. 25. Ibn Şeddad, bu sırada Halep'teki esir Templier şŏvalyelerinin de bundan istifade ile kaçtıklarmı zikrtetmektedir.

"il íbn Bìbî, 2, s. 41-42. 
ancak Humus Eyyubî meliki Melik Mansur'un vaatleriyle Halep meliki enNâsır'a itaat etmiști ${ }^{55}$. Harezmliler Re'sülayn'da ağır bir yenilgi almalarına rağmen bölgedeki güçlerini korumușlardır. Bunun en açık göstergesi Selçuklu Sultamı II. Gıyaseddin Keyhüsrev'in Meyyâfârıkîn'ı Eyyubîlerden almak istemesi karșısında Melik Gazi'nin, Re'sülayn savașından sonra Bağdat tarafina gitmiş, halifenin ilgisini ve himayesini görerek güçlenmiş, topluluklarının sayısı, Şiraz tarafından gelip teçhizatlı askerleriyle kendilerine katılmıș olan Celâleddin'in kız kardeşinin oğlu Yağan Tayși ile çoğalmış olan Harezmlileri yardıma çağırmasıdır. Böylece Berke Han ile Güçlü Han yeniden el-Cezire ve Suriye'ye gelerek hâdiselere katılacaklardır. Merkezde Melik Gazi ve Bereket Han, sağ ve solda Harezmli ve Germiyan kuvvetlerinin bulunduğu Meyyâfârıkîn ordusu Türkiye Selçukluları karşısında dağılmasına rağmen halifenin araya girmesi ile Selçuklu ordusu geri çekilmiştir ${ }^{5 i}$. Yine Selçukluların Moğol tehlikesi karşısında Kösedağ savaşı öncesinde "sayıları hesaba gelmeyen Harezmliler" den büyük bir ordu kurarak onlara Harput'u ikta etmeleri ${ }^{57}$ gibi olaylar onların güçlerini hâlâ koruduklarını göstermektedir.

Burada dikkatimizi çeken bir husus da, Halife ile Harezmliler arasındaki ilişkinin seyri ve bunun Moğollar üzerindeki tesiridir. Ahlat muhasarasına kadar Halife ile Celâleddin arasındaki ilișkiler iyi değildi. Bu ilişkinin Harezmşahlar Devleti'nin kuruluşundan beri İran coğrafyası üzerinde Halifeler ile olan siyasî rekabetin getirdiği bir arka planı vardı. Ancak yukarıda zikrettiğimiz gibi Ahlat'mn alınması ile ilișkilerin seyri değișmiștir. Halife sultana saltanat hil'au gönderirken sultan da hâkim olduğu bölgelerde halifeye dua edilmesine müsaade etmiștir. İlişkilerin bu şekilde düzelmesi Moğolların halifeye olan bakışlarını değiștiren ilk olay olmuștur. Daha sonra Harezmli komutanlardan Berke ve Güçlü Hanların halifeye sığınması ile halifenin onlanı koruma altuna alması ve Selçuklu-Harezmli mücadelelerinde halifenin Harezmliler lehine aracılık yapması Moğolların Abbasî Halifeliği hakkındaki düşüncelerinin netleșmesine katkıda bulunacakur. Zira 1248 yılında Kıbrıs'a St. Louis'in nezdine giden Moğol elçileri Hıristiyanlığın kendi aralarında yayıldığından bahsettikten sonra, "şimdi ise Bağdad'a Harezmlilerin $\mathrm{Hz}$.

\footnotetext{
55 İbn Bîbî, 2, s. 42-43; C. Cahen, Osmanlılardan Önce Anadolu'da Türkler, s. 142.

5 "í İbn Bîbî, 2, s. 55-57.

${ }^{57}$ İbn Bîbî, 2, s. 79-141.
} 


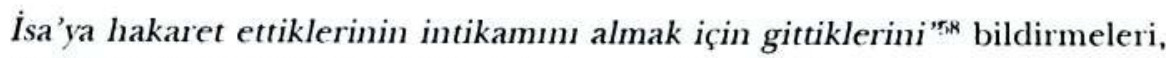
Halife ile Harezmlilerin ilișkilerinin bıı seyri ile alâkalı olmalıdır. Moğolların bu tavrı Selçuklular için de geçerlidir. Çünkü Yassıçemen Savaşı'ndan sonra Selçuklularm Harezmlileri hizmetlerine alarak himaye etmeleri ve Erzurum'u onlara ikta etmeleri Moğollarm ani tepkisi ve Erzurum baskım ile neticelenmiştir. Selçuklularm baskın yapan Moğollan takip etmeleri, Harezmlileri himayede israrlı olarak onlara İç Anadolu'da iktalar vermeleri ve devlet hizmetinde onlara daha önemli yer vererek Moğollara karșı onlardan istifade etmek istemeleri, Moğolların Selçuklular hakkındaki kanaatlerinin pekișmesinde dikkate alınmalıdır. Zira Moğollar, Yakındoğu'da adeta millî hasmı durumuna gelen Harezmlileri koruyanlar için sürekli bir cezalandırma politikası uygulamışlardır.

1242 yilnnda Türkmenler ile birlikte Halep'e saldıran Harezmliler, Suriye Eyyubî meliklerinin ittifakı karşssında tekrar hezimete uğradılar. Bir taraftan gittikleri yerleri yağmalayan veya ilgilenen birine kendilerini para ile kiralayan Harezmliler, diğer taraftan da yaklaşmakta olan Moğol tehlikesi karșısında dayanacakları bir müttefik anyorlardı ${ }^{50}$. el-Kâmil'in 1238'de ölümünden sonra veraset hakkı elinden alınan el-Cezîre Meliki es-Salih Eyyub 1240'ta kardeşi el-Âdil Ebû Bekir'i devirerek Mısır sultanı oldu. Suriye'yi öteki Eyyubî prenslerinin elinden almak isteyen el-Melik es-Salih, Sam ve Kerek meliklerinin Franklarla işbirliği karșısmdata ${ }^{\text {tit }}$ eski müttefikleri Harezmlileri yardıma çağıdı'i!. "Harezmliler, Salih Necmeddin Eyyub'a yardım kastı ile şarktan ayrıldılar ve bu yılın başlarında (1244) Fırat'ı kayı ile geçerek emîr Hüsameddin Berke Han ve Hanberdi (Canberdi) ve Saru Han ve Güçlü Han önderliğinde toplamı 10.000 atlınm üzerinde olarak Fırat'ı geçtikten sonra iki kısma bölündüler. Bir kısmı Baalbek üzerine, bir kısmı Dımaşk üzerine yöneldiler ve yolları üzerindeki Harim ve Dımaşk bölgesinde bir çok tahribat yaptılar" ${ }^{\prime 2}$. Suriye ve Mısır kaynaklarmın geniş

${ }^{58}$ V.V. Barthold, Moğol İstilâsına Kadar Türkistan, Haz.H.Dursun Yıldız, Kervan Yay, İstaubul 1981, s. 615; Elçigiday'ın 1248 yılında Lâtinlerle mektuplaşmaları hakkında bakz. Grosset, s. 333. Bat Huristiyanlarnmun Moğollar ile olan ilişkilerinin geniş bir değerlendirmesi için blz. Runciman, 3, s. 218-249.

74 M.G.S. Hodgson, İslamm Serüreni, C.2, Cev. Heyet, İz Yay., İstanbul 1993, s. 312.

(a) Ibn al-Furat. Tarikh al-Duwal wa'l Mülük, Volum 1; The Text, M.C. Lyons, Cambridge 1971 , s. 1/34b.

(i) İbn al-Furat, s. 3/38b.

ti2 Ibn al-Furat, s. 3/38b. 39a. 
yer verdikleri bu istilâ, Harezmlilerin Yakındoğu siyasî sahnesindeki son oyunlarının başlangıcı idi.

Harezmliler bu istilâ hareketinden sonra Kudüs'e hücum ederek burayı Frankların elinden aldılar ${ }^{63}$. Davud Burcu'na sığman Frankları ortadan kaldırarak Kudüs'e hâkim oldular ve onun beldelerini aralarında paylaştılar $^{\text {it }}$. Şehirde Frankları katleden Harezmliler, Kumame Kilisesi (The Holy Sepulchre)'ni tahrip ettiler ve Harem-i Şerîf'i Hıristiyan sembollerinden temizlediler ${ }^{65}$. Bu arada Dımașk, Kerek ve Hımıs Eyyubîleri ile Frank ittifak ordusuna karşı Mısır sultanı el-Melik el-Salih Necmeddin, Emîr Rükneddin Baybars el-Kencî adlı Memlûk komutasında bir ordu gönderdi. Hıristiyanların Hıttin'den sonra çıkardıkları en büyük ordu ${ }^{\text {thi }}$ ile katıldıkları savaşı Baybars ve Harezmliler kazandı ${ }^{\mathrm{it}}$. Ancak Harezmliler yağmacı tabiatlarmı burada da sergilemișler ve kendilerine ikta edilen beldelerle yetinmeyip hem onları soymusslar hem de çevredeki beldelere saldırmıșlardır. Onların bu tutumu Kayı Han olaymm tamamen bir bahane teșkil ettiğini ve Selçuklulaın hizmetinden çıkmalarının asıl sebebinin yağmacı yapılarından kaynaklandığımı göstermektedir.

Mısır kuvvetlerinin Kudüs'te hâkim olmasından sonra Harezmliler, önce Gazze, arkasından Nablus bölgesine yağma yapmışlardır ${ }^{\text {is }}$. Yağmalarını Kudüs çevresine kadar genişleten Harezmlilere karşı Mısır'dan ordu gönderilmiştir ${ }^{69}$. Dımaşk hâkimi el-Melik Salih, Harezmlilerin bu yağmalama hareketlerinden kurtulmak için Hıms ve Halep melikleri ile birlikte hareket ederek onları Hıms âmilliklerinden tamamen atmışlardır ${ }^{70}$. Onlardan geriye kalan küçük Harezm grupları Kudüs'e dönüp o bölgeleri istilâya başlayınca Mısır'dan bu defa Fahreddin b. Şeyhî komutasında ordu

63 Ibn Şeddad, el-A'lak'ül-Hatire fi Zikri Ümerai'ș-Sam ve'l-Cezire, Tarih-i Lübnan ve'l Ürdïn ve Filistin, C. 1, Tahkik: Sami Dehhan, Dımaşk M. 1962/ H. 1382, s. 234; İbn al-Furat, s. 3-4/39a; İbn Tagribirdi, C. VI, s. 325; Solomon D. Goitein . "Al Kudüs". EI. C.5, Leiden, E.J. Brill, 1978, s. 331; F. Bulh, "Kudüs", IA, C. 6, MEB. Istanbul 1988, s. 961; Claude Cahen, "The Turks in Iran and Anatolia ", s. 674.

(ii) İbu Seddad, el-A'lak, s. 235.

is Ibn al-Furat, s. 4/39a.

${ }^{\text {tit }}$ Rumcıman, Haçlı Seferleri Tarihi, Cev.Fikret Işıltan, C.3, TTK. Ankara 1992, s. 197.

i7 Ibn Seddad, el-A'lak, C.1, s. 235.

is ibn al-Furat, s. 3-4/384,40a.

6. İbn Ședdad, el-A'lak, C.1, s. 247; Bertold Spuler, Iran Mogolları: Siyaset, Idare ve Kültür IIhanhlar Devri, 1220-1350 Cev. Cemal Köprülü. TTK, Ankara 1957, s. 441.

76) İbn al-Furat, s. 5/396-40a; İbn Ședdad, el-A'lak, s. 235. 
çıkarılarak onların bu hareketlerine de son verilmiş ve esir düşenler orduya katılmak üzere Mısır'a gönderilmiștir ${ }^{71}$. Böylece Harezmliler, Mısır ve Suriye Eyyubîlerinin karșısında 1246 'da büyük bir hezimete uğrayarak askerî bir güç olmaktan tamamen çıkmışlardır. Bu savaşta en ünlü liderleri Berke Han öldürülüp başı Halep'e gönderilerek oradaki kalede teșhir edilmiștir ${ }^{72}$.

\section{2- Harezmlilerin Yakındoğu Türk-İslâm Devletlerinin Hizmetine Girmeleri}

1246 yılında askerî bir güç olmaktan tamamen çıkan Harezmliler için yeni bir dönem başlıyordu. Bunların bir kısmı doğuya yönelerek Abbasîlerin ve Moğolların hizmetine girmișlerdir. Hülagu'nun Bağdad seferi esnasında Moğol hizmetinde bulunan Harezmli unsurların beylerinden Sultancuk, halife ordusunun öncü kuvvetleri komutanı Kara Sungur ile olan kavmiyet birliğini ileri sürerek onu İlhan'm hizmetine girmeye davet etmiştir ${ }^{73}$. Kara Sungur'un dışında yukarıda da zikrettiğimiz gibi Halife'ye sığınan başka Harezmli unsurlar da bulunmakta idi. Bu dönemde Moğolların hizmetine giren bir diğer Harezmli komutan, onların Selçukluların hizmetine girmesinden itibaren Yakındoğu hâdiselerinde ismi sık sık geçen ve daha önce halifeye sığınan Güçlü Han'dır. Harezmli komutanlardan olarak bahsedilen Güçlü Han, Ayn Calut öncesinde Eyyubî Meliki Nâsır'ın, Mucîreddin İbn Ebî Zıkrî kumandasındaki ordusunu ve başta Ebî Zıkrî olmak üzere Nureddin el-Akta ve İbn Durbas gibi ileri gelen komutanlarmm yenmesi ile zikredilmektedir ${ }^{74}$. Güçlü Han, Moğolların hizmetinde Güneydoğu Anadolu bölgesindeki istilâlar esnasında öldürülmüștür ${ }^{75}$. İlhanlı hükümndarı Hülagu 1258 yılında Bağdad'ı kuşattuğı zaman bile șehri halifenin hassa ordusunu meydana getiren Kıpçak ve Harezmliler ile Yıva Türkmenleri savunmuştu ${ }^{76}$. Buradaki Harezmlilerin başında yukanda zikrettiğimiz Kara Sungur bulunuyordu. Suriye ve Filistin'deki Harezmlilerin bir kısmı ise Eyyubî ve Mısır Memlûklularımın

71 Ibn Şeddad, el-A'lak, C.1, s. 235; Tekindağ, "Memlûk Sultanlığı Tarihine Toplu Bir Bakıș”, Istanbul Üniversitesi Edebiyat Fakültesi Tarih Dergisi, s.5.

72 İbn Tagribirdi, C. 6, s. 325; M.H. Burgoyne, Mamluk Jerusalem, London 1967, s.110; Runcıman, 3, s. 264; M.C.Şehabeddin Tekindağ. Berkuk Devrinde Memlûk Sultanlığı, IUUEF Yay.No:887, İstanbul 1961, s. 5 .

${ }^{73}$ Cüveynî, s. 586-587; F. Sümer, "Anadolu'da Moğollar", s. 27; B. Spuler, , Iran Moğolları, s. 495 .

${ }^{7}$ ibn Seddad, el-Alak, C.1, s. 249.

75 İbn Tagribirdi, C. 7, s. 25.

${ }^{76}$ Ekrem Pamukçu, "Moğol İstilâsına Karșı Irak Türkmenlerinin Bağdad Savunması", Gazi Üniversitesi, Fen-Edebiyat Fakültesi, Sosyal Bilimler Dergisi, C. I, yll: 1996, s. 232. 
hizmetine girerek, bu devletlerin düzenli orduları içerisindeki yerlerini almıșlar ve onlardan ayrı bir Memlûk sınıfı teșkil edilmiștir ${ }^{77}$. İsâm âleminde adeta son sığınak noktasını teşkil eden Mısır'a sığınan önemli Harezmli komutanlar arasında, Hüsameddin Berke Han, Melik İhtiyar, Melik Seyfeddin Sâdık Han, Nâsıreddin Güçlü Han, Atlas Han ve Nâsıreddin Kaymerî gibi daha önceleri Harezmşahlar Devletinde ve ordusunda önemli görevler almıș olan komutanlar bulummakta idi ${ }^{78}$. Ancak Eyyubîler, Harezmliler gibi göçebe karakteri ağır basan yağmacı toplulukları Mısır ve eyalet merkezleri ile önemli șehirlerin dışında ıssız bölgelere yerleștirmişlerdir ki onların takipçisi olan Mısır Memlûkları da Harezmli ve Moğol boylarına mensup toplulukları sahil bölgelerindeki ıssız alanlara yerleștirmişlerdir ${ }^{70}$. Eyyubî sultanı el-Melik es-Salih (1205-1249), Mısır'da çoğalan ve çoğunluğunu Kıpçak ve Harezmlilerin teşkil ettiği bu Memlûk unsurlar ${ }^{80}$ arasından, el-Mamâlik alBahriyye olarak adlandırılan ayrı bir Memlûk grubu kurmuştur ki bunlar 1260 Ayn Calut savașında önemli rol oynamışlardır ${ }^{81}$.

Diğer taraftan Memlâk sultanı Kutuz (1259-1260), kendisini Harezmşahlar hanedanından saymaktadır. Annesinin Celâleddin Harzemşah'ın kız kardeși, babasının ise aynı zatın amcasımın oğlu olduğu kabul edilmektedir $^{82}$. Yine Kudüs'de Harem-i Şeriff (Kudüs ve el-Halil) nâzırlarından elHarezmî nisbesini tașıyan kimselere de rastlanmaktadır ${ }^{83}$. Ancak Harezmlilerin Memlûk devleti içindeki en önemli rolleri ünlü Harezmli liderlerden Hüsameddin Berke Han b. Devlet Han el-Harezmî el-Yemkî'nin* sultan Bay-

${ }^{77}$ S. Tekindağ, "Memlûk Sultanlığı Tarihine Toplu Bir Bakıș", s.5-6.

is Abdulkadir Yuvalı. IIhanlılar Tarihi I Kurulus Devri. Ercives Üniversitesi Yaynnları, Kayseri 1994, s. 342-343; S.Tekindağ. Berkuk Devrinde Memlûk Sultanlığı, IUUEF Yay.No:887. Istanbul 1961s. 34. 70nd.; Ș. Tekindağ, "Memlûk Sultanlığı Tarihine Toplu Bir Bakıș", s.5.

79 Aynî, C. III, s. 305; David Ayalon, Outsiders in The Lands of Islam: Mamluks, Mongols and Eunuchs, Variorum Reprints, London 1988, s. IVc/ 134-135.

${ }^{80}$ KâzımYașar Kopraman, Mısır Memlûkleri Tarihi, KBY, Ankara 1989, 3-4; Z.Velidi Togan, Umumi Türk Tarihine Giriș, Enderun Kitabevi, İstanbul 1981, s.179.

${ }^{81}$ Runciman, III, s. 264.

82 M.C.Sehabeddin Tekindağ, "Kutuz", IA, C.6, s.1057; Philip K. Hitti, Siyasî ve Kültürel İslam Tarihi, 2. Çev. S. Tuğ, Marmara Üniv. İlahiyat Fak. Yay., İstanbul 1995, s.1091; Z.V. Togan, Umumî Türk Tarihine Giriş. s. 179.

${ }^{8.3}$ D.P.Little, "Relation Between Jerusalem and Egypt". History and Historiography of the Mamlûk, Variorum Reprints, London 1986, s. 86.

* A. N. Poliak ve onun takipçilerinden Lane-Poole ve Bartold gibi oryantalistler Harezmli Berke Han'ı Altunordu hükümdarı Berke Han ile karıșturmışlardır. Zira Barthold bundan dolayı Mısır kaynakłarının Memlûk-Altunordu ilişkilerini 1262'de bașlatmasım şüpheli bulmaktadır. Oysa el-Melik es-Said Berke Han babasımun saltanatundan on ay ònce 1260 Ocak'inda doğmuştur ve bu Memlûk Devleti ile Altunordu ilişkilerinin başlamasından iki yıl öncedir. Bkz. V.V. Bartold, Orat Asya Türk Tarihi Hakkında Dersler, Yay.Haz. K.Y.Kopraman-A.Ismail Aka, Kültür 
bars ile kurduğu akrabalıktur. Baybars, Berke Han'ın kızı ile evlenmiş ve ondan olan oğlu Melik Saîd Muhammed Baraka (Berke) Han'ı da ölmeden önce sultan ilân etmiştir's! . Harezmli komutan Hüsameddin Berke Han'm Baybars ile evlenen bu kızının yanında Bedreddin Muhammed Bey ve Hüsameddin Kara Bey adlı iki oğlu da bulunuyordu. Bu hanedan denemesi verasete karşı olan Memlûk mantığ ${ }^{85}$ karşısında başarılı olamamış $1279^{\prime}$ da Suriye'deki bir isyan sonrasında tahtan indirilerek Memlûk hükümdar ve yakınlarının sürgün edildiği Kerek'e gönderilmiştir ${ }^{k i}$.

Kudüs'teki Berke Han Türbesi 1246 yılındaki savașta hayatunı kaybeden ünlü Harezmli komutan Hüsameddin Berke Han'a aittir. Muhtemelen biri inşa, diğeri restorasyonuna ait olan ve 1246 tarihli iki kitabesi bulunan türbenin ne zaman ve kimin tarafından yaptırıldığı tam olarak bilinemiyor. Tarik Bab es-Silsile'de bulunan türbenin Berke Han tarafindan ölmeden önce inşa edildiği veya inşasına başlandığı düşünülebilir. Zira Osmanlı defterlerinde "Barka Hatın Vakfi " adlı bir vakfın varlığı türbeye gelir sağlamak amacıyla kurulmuş olduğunu düşündürmektedir ${ }^{87}$. Bunun yanında türbenin, kızı tarafından babasının haturasına inşa edilmiş olabileceğini Van Berchem iddia etmekle ${ }^{\mathrm{R} 8}$ birlikte oğlu Bedreddin Muhammed Bey tarafindan da inșa edilmiș olabilir. Barka Han Türbesi'nin daha sonra bu vasfı ile kaybolduğu ve XX. asrın başında Kudüs'teki Şeyh Ragıb el-Halidî tarafından büyük bir kütüphaneye dönüștürüldüğü anlaşılmaktadır".

Bakanlığı, Ankara 1975, s. 239-240; Ayalon, s. Ivc/ 144-145. Ayrıca Bartold, Altunordu hükümdarı Berke'nin ordasında bulunan Mısır elçilerinin hamın oğlu olmayıp kızlarımın bulunduğunu açıkça bildirmelerini aktarmasına rağmen 1279 yılında ölen Harezmli Hüsameddin Berke Han'ı oğlu Bedreddin Muhammed Bey'i Alunordu hükümdarı Berke Han'm oğlu zannetmiștir. Bakz. Bartold, Dersler, s. 240. Bunun yanında İbn Tagribirdi, Berke Han'ı Berke Han b. Devlet Han el-Havarazmi adıyla anarak onun Harezmli olduğunu açıkça zikretmektedir. Ibn Tagribirdi, C. V.7, s. 259.

'4t İbn Şeddad, Baypars Tarihi, s. 116; Fuad Köprülü, "Baybars I", IA, C. II, MEB, İstanbul 1999, s. 362; K. Y. Kopraman, "Baybars I", DIA, C. 5, İstanbul 1992, s. 222; P.M. Holt, Haçlılar Căğı 11. Yüzyıldan 1517'ye Yakındoğu, Çev. Ö. Arıkan, Tarih Vakfı Yurt Yay., İstanbul 1999, s. 101.

${ }^{85}$ K. Yaşar Kopraman, "Memlûkler", Doğuştan Günümüze Büyük Íslam Tarihi, C. 6. Çag̃ Yaynlan, İstanbul 1992, s. 468.

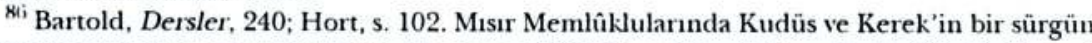
yeri olarak kullanılması hakkında bkz. Muammer Gül, "Mısır Memlüklarında Bir Sürgün Sistemi Olan Battallık ve Kudüs", Belleten, C. LXVI, S. 246, s. 366.

${ }^{87}$ Burgoyne, s. 109-110.

k太 Max Van Berchem, Corpus Inscriptionum Arabicorum, Kahire 1922, s. 185 vd..

89 G.Walls, "The Turbat Barakat Khan or Halidi Library", Levant, Vi, 1974, s. 25, vd. 
Hüsameddin Berke Han'ın oğulları ve Baybars'in oğlu Melik Said Muhammed Berke Han'm daylan olan Bedreddin Muhammed ve Hüsameddin Kara Beylerin Memlûk devleti içerisinde iyi bir konumda oldukları anlaşılmaktadır. 663/1264-5 yılında sultan Baybars, Haçhılardan yeni alınan sahil bölgelerini emîrlerine dağıtırken Dayr al-Gülsüm Köyü'nü Bedreddin Muhammed Bey'e mülk olarak vermiștir. Kudüs'te, mescidi ve türbesi ile "Bedreddin b. Barka Han Vakfı"nın bulunması onların durumlarını izah etmektedir. Bedreddin Muhammed, yaklaşık 50 yaşında 1279 yılında Şam'da öldükten somra Kudüs'e getirilerek babasının yanında defnedilmiştir ${ }^{90}$. İbn Şeddad'ın "Emîr " olarak bahsettiği Bedreddin Muhammed Bey'in, Baybars devrinde bir hamam yaptırdığı da kaydedilmektedir"1 ki, bütün bunlar Harezmlilerin Mısır Memlûk Devleti içerisinde sosyal ve ekonomik yönden iyi bir durumda olduklarını göstermektedir. Bedreddin Muhammed Bey'in ayrıca iki ciltlik Arapça şiir, kelâma dair eserler ve bir de Kứan-ı Kerîm tefsiri kaleme aldığı rivayet edilmektedir ${ }^{92}$. Hüsameddin Kara Bey ise, 1263 yılında ölmüş ve Kahire'de gömülmüştür ${ }^{93}$. Harezmliler bu dönemde Memlûkların dışında Musul emîri ile de bir akrabalık kurmuşlardır. Zira Celâleddin Harezmşah'ın iki yaşındaki kızı Türkan (Terken) Hatun, Moğollara esir düştükten sonra sarayda yetiştirilmiş ve kendisine lâyık biri ile evlendirilmesi için Hülagu'ya verilmiştir. Hülagu ise onu 1257-8'de Musul emîri Bedreddin Lülü'nün oğlu Melik Salih İsmail ile evlendirmiştir"'t. Terken Hatun daha sonra Musul emîri Salih'e karşı Moğollardan yana tavir alarak dönemin siyasî olaylarına karışacakur ${ }^{95}$.

Ancak gerek Harezmli emîr ve ileri gelenlerin ve gerekse Harezmli Türk topluluklarının Yakındoğu'da en fazla rol oynadıkları ve iz bıraktıkları coğrafya Anadolu olmuştur. Kayır Han olayından sonra Harezmlilerin önemli bir kısmı el-Cezîre ve Suriye bölgesine gitmesine rağmen bir kısmı Anadolu'da kalınıstur ${ }^{\text {ini }}$. Suriye ve Filistin bölgesine giden Harezmlilerin bir kısmının ise gerek oradaki maceralarının sonuçsuz kalması ve gerekse

${ }^{90}$ Burgoyne, s. 110. Bartold ise, Bedreddin Muhammed'in 1280 yllnda Kahire'de yüksek bir yerden aniden düşerek öldüğünü zikretmektedir. Bakz. Barthold, Dersler, s. 240.

"IIbn Şeddad, Baybars Tarihi, 174.

12 Barthold, Dersler, s. 240.

3 Burgoyne, s. 110.

${ }^{94}$ Cüveynî, s. 382-3; Abu'l Farac, Ebu'l Farac Tarihi, 2, 564.

95' Abu'l Farac, Ebu'l Farac Tarihi, 2, 580.

'hi Faruk Sümer, "Azerbaycan'ın Türkleșmesi Tarihine Umumî Bir Bakış", Belleten, C.XXI, S. 83,TTK, Ankara 1957, s. 435. 
Selçuklu sultanları arasındaki mücadele ve Moğollara karşı onlardan istifade etme istekleri sonucunda Anadolu'ya geri geldikleri anlașılmaktadır ${ }^{97}$. Harezmlilerin daha Anadolu'ya ilk geldikleri tarihten itibaren Kayır Han gibi emîrlerin yanında önemli Harezmli bürokratlar da Selçukluların hizmetine girmişlerdir. Bunların başında, daha önce Celâleddin'in Keykubad'a elçi olarak gönderdiği ve ülkesinin baș kadılığını yapmıș ve vezir sıfatı bulunan Taceddin Mu'tez İbn Muhyiddin Tahir gelmektedir"s. İbn Bîbî'nin Mucîreddin Tahir b. Ömer el-Harezmî olarak tamıttğı bu kiși ${ }^{m,}$, Moğollar adına borçların tahsil amacı ile ve kararlașturılan miktarın ödeneceğine bir güvence olarak, Kastamonu, Develihisar ve Aksaray'ı ikta olarak almıştır. 1277 yllında ölen Taceddin' in yerine oğlu Mucîreddin Muhammed b. el-Mu' tez, 679 (1280-1281) yılında Abaka'nın huzurunda aldığı hilat, payza ve yarlığ hükmü ile babasının makamına oturmuştur ${ }^{100}$. Daha sonra saltanat naipliğini ve Rum emîrliğini alması ve arkasından ülkenin sahip Kazvinî ile Emîr Mucîreddin arasında bölünmesi ${ }^{101}$ (1289-91) bu baba-oğulun Anadolu siyasetindeki rolünü göstermesi açısından önemlidir.

Bu dönemde Anadolu'da etkili bir role sahip olduğunu gördüğümüz Harezmli emîrlerden biri de Emîr Hüsameddin Bicar ${ }^{102}$ ve oğullarıdır. Anadolu'daki kıdemli emîrlerden olarak bahsedilen Hüsameddin Bicar ${ }^{103}$, Celâleddin Harezmşah ile birlikte I. Alaaddin Keykubad'a karşı savaşmak üzere Anadolu'ya gelmiş ancak Harezmî ordusunun yenilgisinden sonra Rum'da kalmıș, devletin büyüğü ve Diyarbakır çevresinin komutanı olan Bicar Bahadır'ın babasıdır ${ }^{104}$. Hüsameddin Bicar, Harput bölgesine sahip iken oğlu Diyarbakır bölgesine sahip bulunuyordu. Husameddin Bicar ve oğlu Bicar Bahadır'm yanında Sadraddin Kutluşir, Zeyneddin Ali Bahadır, Cemaleddin Horasanî gibi emîrler Türkiye Selçuklularnmın iç mücadelelerinde ve bilhassa II. Izzeddin Keykâvus ve IV. Rükneddin Kılıç Arslan arasındaki mücadelelerde önemli rol oynadılar ${ }^{105}$. Ancak Anadolu'da artık tutunama-

:17 Ibu Bîbî, 2, s. 79,141.

!I Kerimüddin Mahmud Aksarayî, Müsameretï'l Ahbar. Cev. Mürsel Öztürk, TTK. Ankara 2000, s. 49-50, 78-81; Turan, Selçuklular Zamanunda Türkiye, s. 363.

(n) İbn Bîbî, I, 374-379.

${ }^{100}$ Aksarayî, s. 105; İbn Bîbî, 2, s. 156-157.

${ }^{101}$ Aksarayî, s. 108, 117-118, 122, 144, 195.

${ }^{102} \mathrm{Bu}$ ismin kaynaklarda Bicar, Baycar, Bencar, Beycar gibi farklı yazılıșları vardır.

103 İ̉on Bîbî. 2, 120.

${ }^{104}$ İbn Ședdad, Baybars Tarihi, 61; Aksarayî, s. 77.

105 İbn Bîbî, 2, s. 120,139-140-141; İbn Şeddad, Baybars Tarihi, 61,72-76. 
yan Hüsameddin Bicar, Muîneddin Pervane'nin de teşviki ile oğlu Bicar Bahadır ve torunları Muîneddin ve Muzafereddin ile birlikte Mısır sultanına sığındılar ${ }^{10 i}$. Aynî ise, Memlûklere sığınan bu mültecileri, Bencar (Bicar) elRumî, onun oğlu Bahadır, Ahmed b. Bahadır, on iki Rum emîri ve onların evlatları ve bağlıları ile Kurmışı ve Şektay ve onların kabilesinin neferleri olarak zikretmektedir ${ }^{107}$. Bunlar Doğu ve Güneydoğu Anadolu bölgesinde Celâleddin Harzemşah zamanından beri bulundukları için bu bölgedeki topluluklarla kaynaşmıșlardır. Bu iç mücadeleler sırasında bunların maiyyetinde Kıpçak, Harezmli, Kürt ve Arap unsurların bulunması ve Bicar Bahadır'ın Diyarbakır'da Kürt beyi olarak anılması ${ }^{108}$ bu durum ile alâkalı olmalıdır. Ayrıca bu Harezmli emîrlerden hemen önce Şektay ve kardeşi Çaverçi de Şam'da Memlûklara iltica etmişlerdir ki Bicar Bahadır bu iki Moğol komutanının eniştesi idi' ${ }^{109}$. Bicar ailesi ve yanındakiler muhtemelen Şektay ve Çaverçi adlı bu iki Moğol komutanı tarafindan Baybars'a takdim edildiler ve Baybars'ın Anadolu'ya gelmesini teșvik etmek için Muîneddin Süleyman Pervane tarafından teşvik edildiler ${ }^{110}$. H. 710 (1310-1311) yılı olayları arasında Mısır Memlûk Devleti'ndeki saltanat mücadelelerinde Bicar adlı bir beyden bahsedilmektedir ${ }^{111} \mathrm{ki}$ bu dönemdeki Memlûk saltanat mücadelelerinde Moğol ve Harezmli unsurların faaliyetlerinin bir yansıması olarak görülmelidir. Bu Moğol ve Harezmli unsurların Memlûklara iltica etmesinde, Altınordu hükümdarı Berke Han'ın kendi kabilesinden Moğolların Memlûklara katılmasını istemesi ve Harezmlileri Kahire'de karșılayan Baybars'ın oğlu el-Melik es-Saîd'in anne tarafindan Harezmli olması, yani Harezmli ünlü emîr Husameddin Berke Han'ın torunu olması kanaatimizce önemli bir sebep teșkil edecektir.

Celâleddin Harzemşah ile birlikte Hindistan'dan Anadolu'ya kadar gelen emîrlerden biri de Orhan'dır. Celâleddin' in Hindistan'daki mücadelede adı geçen ve dayısının oğlu olan Orhan ${ }^{112}$, Celâleddin'in kardeşi Glyaseddin'den ayrılarak kendisine katılmıştur. Orhan, ilk olarak Sultan Celâ-

I\%i İbn Seddad, Baybars Tarihi, 76,156.

${ }^{107}$ Aynî, C. 2, s. 152.

108 Aksarayî, s. 77; İbn Bîbî, 2, 139-140-141.

${ }^{10 \%}$ İbn Şeddad, Baybars Tarihi, 72-75; Aynî, 2, s. 152.

${ }^{110}$ R. Amitai-Preiss, Mongols and Mamlûks The Mamlûk-Ilkhanid War, 1260-1281, Cambridge 1996, s. 165.

111 Takyu'd-Din Ahmed b. Ali el-Makrizi, Kitabu's-Süluk li-Ma'rifet-i Düveli'l-Müluk, Tashih ve Haşiye: M. Mustafa Ziyade, Kahire 1941, Türkçe tercüme: Zakir K. Ugan, TTK Ktp. Daktilolu tercüme yazmalar, s. 75 .

${ }^{112}$ Nesevî, s. 82. 
leddin'in Gürcistan seferinde zikredilmektedir. Gürcü seferinden hemen sonra sultan onu Gence bölgesine göndermiș ve Gence ile beraber Arran da Celâleddin'e tâbi olmuştur ${ }^{113}$. Genceli Kiragos, Kafkasya'da Harezmlilerin istilâlarını anlaturken, Orhan hakkında onların ileri gelenlerinden ve aynı zamanda Sultanın annesi ile evli olarak bahseder. O, Orhan'm Gencak denilen şehirde zulüm yaptığını zikrettikten sonra onun aynı șehirde İsmailîler tarafından 1227 yılında öldürüldüğünü söylemektedir ${ }^{114}$. Bunun üzerine Celâleddin, İsmailîlerin bu tecavüzünü cezalandırmak ve yakın akrabası Orhan'ın öldürülmesinin intikamını almak üzere Alamut ve çevresini istilâ ederek yağmalamıştır ${ }^{115}$. Ancak İbnü'l-Esîr 1227 yllı olaylarında Orhan'ın ismini zikretmeksizin Celâleddin'in Gence'yi emirlerinin en ilerisi ve en iyisine ikta olarak verdiğini kısaca nakletmektedir ${ }^{116}$. Oysa Celâleddin, Harezmşah dönemini en geniş şekilde anlatan ve sonraki yazarların başlıca kaynağı olan Cüveynî, Orhan'ı Celâleddin'in ordusunun öncü birlikleri komutanı olarak tanıtmakta ve 1231 yılında Diyarbakır önündeki ani Moğol baskınında, Moğolları oyalayarak Celâleddin'in kaçmasına yardım etmiş ve daha sonra kendisi de kaçarak kurtulmuş olarak tanıtmaktadır ${ }^{117}$. Dönemin en önemli kaynağı ve olayın tanığı olan Nesevî de Orhan'ın Gence'de İsmailîler tarafindan öldürüldüğünü ${ }^{118}$ zikretmektedir. Ancak o, daha sonra Diyarbekir önlerindeki son Moğol baskınında Orhan'ın Moğollara saldırdığını ve Sultanı kurtarmak için Moğol askerini üzerine çektiğini, arkasından önce Erbil'e gittiğini oradan Isfahan'a giderek orayı işgal ettiğini, Moğollar oraya geldikten sonra Fars' çekilerek 1241 yılına kadar orada kaldığını söylemektedir ${ }^{119}$. Bundan dolayı İbnü'l-Esîr'in ismini zikretmediği ve İsmailîler tarafından öldürülen bu Gence emîrinin gerçekten Orhan olup olmadiğını tam olarak bilemiyoruz.

Celâleddin ile Anadolu'ya gelen diğer bir emîr Buku Han'dır. Celâleddin, Yassıçemen savaşından sonra, önce Kafkasya'daki konumunu güçlendirmek ve daha sonra da Diyarbakır'a hareketi sırasında, Buku Han'ı Moğolların hareketini takip için Azerbaycan'a göndermiştirir ${ }^{120}$. Celâleddin'in

\footnotetext{
${ }^{113}$ Nesevi, s. 71, 73, 78; A. Taneri, s. 29-30.

114 Kiragos, s. 6-7.

115 İbnü'l-Esîr, C. 12, s. 432; A. Taneri, s. 59.

116 İbnü'l-Esîr, C. 12, s. 432.

117 Cüveynî, s. $347,374-375$.

118 Nesevî, s. 82-83.

119 Nesevî, s. 156.

${ }^{120}$ Cüveynî, s. $372-373$.
} 
ölümünden sonra kaynaklarda bu emîrden de bahsedilmiyor. Ancak Celâleddin'in dedesi Harzemşah Muhammed Tekiş'in 1195 yılında Kayır Buku Han adlı bir emîr ile savaştğg ${ }^{121}$, daha sonra da Kadir Buku Han adlı emîr üzerine saldırarak onu önce esir aldığı, sonra da ona emîrlik vererek hizmetine aldığı kaydedilmektedir ${ }^{122}$. Bizce bu iki şahsın aymı kişi olması muhtemeldir ki, Cüveynî'nin aynı şahısları farklı isimlerle anması da bunu kuvvetlendirmektedir. Burada asıl önemli olan husus ise, Celâleddin'in Azerbaycan ve Anadolu'daki faaliyetlerinde yanında bulunan ve onun ölümünden sonra da 1237'deki ölümüne kadar Harezmlilerin lideri olan Kayır Han'ın da bizce yukarıda zikrettiğimiz Kayır Buku Han ile aynı kişi olma ihtimalidir. Celâleddin'in ölümünden sonra Kayır Buku Han ismine artuk rastlanmiyor. Ama Kayr Han ismi Anadolu'daki Harezmlilerin en önde gelen bir komutanı olarak karşımıza çıkmaktadır. Kaynakların onu Harezmli emîrler içinde ön plana çıkarmaları Harezmşah Muhammed Tekiş döneminden beri Harzemşahlar Devleti içindeki konumundan ve geçmişinden kaynaklanmaktadır. Bu da Kayır Buku Han ile Kayır Han'ın aynı kişi olduğunu kuvvetlendirmektedir.

\section{3-Anadolu ve Cevresinde Harezmli İzleri}

Moğol istilâsının Türkiye'nin siyasî, etnik-kabilevî ve kültür tarihine bir katkısı da hanedan soyundan olanlar ile beraber bütün bu Harezmli emîr ve idareciler ile onların emrindeki Harezmli Türkleri'nin Türkiye tarihinde yer almalarıdır. Gerek bașlangıçta Celâleddin ile gelenler ve gerekse daha sonra İran, Kafkasya ve Suriye'den gelenler artık Anadolu'da yerleşmişlerdir ki bunlara ait hatıralar ve izler bugüne kadar gelmiştir.

Bu hatıralardan ilki, Celâleddin'in Anadolu'daki akıbeti hakkındaki farklı haberlerdir. Her ne kadar çağdaş kaynaklar onun Diyarbakır bölgesinde öldügünü ve Meyyâfârıkin'de defnedildiğini yazarlarsa da Tunceli'nin Hozat ilçesinde "Docik Baba" olarak bilinen Tacik Baba ziyaretgâhının Celâleddin Harzemşah'a ait olabileceği şeklindeki kanaat dikkate şayandır. Buna göre Celâleddin'in, Meyyâfârıkîn-Hazro-Palu istikametinde Murat Suyu'nu geçtikten sonra Dersim dağlık bölgesine sığınması uzak bir ihtimal değildir. Moğolların onu takip edememeleri de onun Dersim

${ }^{121}$ Cüveynî, s. 270.

122 Cüveynî, s. 273-274. 
bölgesine gelmiș olabileceğini göstermektedir ${ }^{123}$. Onun Meyyâfârıkîn'de öldürüldüğüne dair genel görüșe rağmen Harput'ta öldürüldüğü şeklinde kayıtlar da vardır ${ }^{124}$. Ayrıca Anadolu'da muhtelif aşiret, boy ve oymaklar, bilhassa Şiîler ve Dersim bölgesindeki aşiretlerin Celâleddin'e mensubiyet iddiaları ${ }^{125}$ ile Tunceli bölgesindeki aşiret isimlerinde Kafkasya'dan gelen Harezmli topluluklarmn izlerinin varlığ ${ }^{126 i}$ da dikkate şayandır.

Bunlara ek olarak Erzincan-Dersim ve Bingöl-Kığı-Muş-Varto hatu boyunca yaşayan Hormek kabilesi mensuplan, atalarından gelen rivayetlere dayanarak, kendilerini Harezmli Türkleri olarak kabul etmektedirler ${ }^{127}$. Gerçekten de yukarıda zikrettiğimiz gibi Celâleddin Harezmşah ile birlikte Ahlat kușatmaları öncesinde ve sonrasında buralarda yağma ve istilâlarda bulunan ancak önce Yassıçemen ve nihayet Diyarbakır yakınlarında uğradığı son yenilgiden sonra Celâleddin'in hayatımı kaybetmesi ile Harezmlilerin adı geçen yerlerdeki dağlık bölgelere çekilmeleri dikkate alınırsa Hormek kabilesinin Harezmliler ile ilișkisi daha iyi anlașılabilir. Her ne olursa olsun bölgenin etnik- kabilevî yapısında ve kültüründe Harezmli izleri kendisini açıkça göstermektedir.

Doğu ve Güneydoğu Anadolu'da olduğu gibi Batu Anadolu'da da Harezmli Türklerinin izlerini aşiret, boy ve oymak isimleri ile yer adlannda görmek mümkündür. Batı Anadolu'da bir beylik tesis eden Saruhan'ın kaynaklarda zikredilen Harezmli kumandanın bir halefi olması mümkündür ki, Alașehir yer adlan, böyle bir münasebeti kuvvetlendirmektedir. Muğla'daki Horzum adlı yerleșim ismi buna delalet ettiği gibi ${ }^{128}$ Kütahya, İçel, Teke ve Alâiye'de Harzem adlı cemaat-ı Yörükandan aşiret ve cemaatlar ${ }^{129}$, Kütahya-

123 Nazmi Sevgen, Doğu ve Güneydoğu Anadolu'da Türk Beylikleri, Yay. Hazırlayan: Ș. Kaya Seferoğlu-H.Kemal Türkōzü, Türk Kültürü Arașturma Enstitüsũ, Ankara 1982, s. 3.

${ }^{124}$ Ahmed Eflakî, Menâkıbu'l-Ấrifin, C.I. Cev.T. Yazıc1, MEB, İstanbul 1964, s. 22.

125 Bilal Aksoy, Tunceli, C.I. Ankara 1985, s.135-136; M.H. Yinanç," Celâleddin Harzemşah", s. 53. Dersim bölgesi halkımın bu kanaatum dile getiren isimlerden biri de Dersim milletvekili Hasan Hayri Bey'in 3 Ekim 1921 tarihli BMM gizli oturumundaki konuşmasıdır. Bakz. Enver Konukçu, “Kara ve Akkoyunluların Yurdunda”, Türk Dünyası Araşturmaları, S. 86, Ekim 1993, s. 180-181.

12 i İbrahim Yılmazçelik, Dersim Sancağı, Elazığ 1999, s. 125-127.

${ }^{127}$ Mehmet S. Furat, Doğu Illeri ve Varto Tarihi, Türk Kültürü Arașturma Enstitüsü, Ankara 1983, s. 72-87.

${ }_{128}$ P. Wittek, Menteşe Beyliği 13-15 Asırda Garbi Küçük Asya Tarihine Ait Tetkik, Çev. O.Şaik Gökyay. TTK, Ankara 1986, s.19,162; F. Sümer, Oğuzlar, 181, 228, 318, 357.

${ }^{12 .)}$ Cevdet Türkay, Başbakanlık Arşiv Belgelerine Göre Osmanlı Imparatorluğında Ovmak Aşiret ve Cemaatlar, İstanbul 1979, s. 88-408; I.H. Uzunçarşıl,. Anadolu Beylikleri ve Ak-Koyunlu Kara Koyunlu Devletleri, TTK, Ankara 1998, s.39. 
Aydın-Saruhan-Yalvaçta Horzum adlı Yörükan taifesi ${ }^{130}$ yine Kütahya'da Horzum-ı Kebîr, Horzum-ı Atîk, Horzum-ı Cedî $d^{131}$, adlı toplulukların varlığı XIII. yüzyılın sonunda uç bölgelere sığınan Türkmen boyları içerisinde Harezmlilerin etkisini göstermesi açısından önemlidir. Ali Bahadır'ın da Ankara ve Bat Anadolu'daki isyan ve faaliyetlerinde ${ }^{132}$ buradaki Harezmli Türklere dayanması onun Harezmli Türklerden olabileceğini akla getirdiği gibi Afyon bölgesindeki Yörükler arasında da Harezmliler bulunmaktadır ${ }^{133}$. Ayrıca Çukurova bölgesinde Torosların Aladağ kısmında atalarının Aydın'ın Alașehir kasabasından geldiğini söyleyen ve Maraș, Kozan, Kayseri ve Sivas taraflarındaki obalar ile birlikte sayılan iki bin çadın bulan Horzum așireti yamında yine Torosların Binboğa kısmında yaşayan ve atalarının Horzum'dan Bingöl'e, daha sonra da Binboğa dağlarına geldiğini söyleyen Horzum obası mensupları ${ }^{134}$ da Harezmli Türklerinin Anadolu'daki uzantılarını teşkil etmektedirler.

Diğer taraftan Mardin'nin güney-batısında VI. yüzyıldan beri Bizans İmparatorluğu'nun doğu sınırlarını koruyan bir kale olan ve Bizans döneminden beri varlığı bilinen Harzem adlı önemli bir yerleşim bulunmaktaydı $\mathrm{ki}^{135}$, burayı Mardin Artuklu emîri Kutbeddin'nin imar edip bağ ve bostan yaptı̆ı 1 kaydedilmektedir ${ }^{13 i}$. Bitlis'te H. 800, 1014 ve 1092 tarihli tescil kayıtlarında bulunan bir vakfiyenin şahitleri arasında Mevlâna Şerefeddin el-Hılatî el-Harezmî1 ${ }^{137}$ adı dikkati çekmekte ve onun Ahlat'a yerleşmiş Harizmli unsurlardan geldiği anlaşılmaktadır. Urfa merkez köylerinden Horzum ve Küçük Horzum adlı köyler ${ }^{138}$ ile Urfa-Siverek'te Harzunî ${ }^{139}$ adlı köy de onlarnn Urfa bölgesindeki hâkimiyetlerinin birer haturası olarak kalmışur.

${ }^{1: 30}$ Türkay, s. 422.

131 Türkay, s. 90.

132 İbn Bîbî, 2, s. 151,160-161,164.

133 Yusuf Z. Yörükan, Anadolu'da Alevîler ve Tahtacılar. Haz.Turhan Yörükan,TTK. Yay.. Ankara 1988, s. 411.

${ }^{13}$ Ali Rıza Yalman, Cenupta Türkmen Oymakları, II, Haz. Sabahat Emir, Kültür Bakanlı̆ıı Yayınları, İstanbul 1993, s. 36-37, 360-362.

${ }_{135}^{135}$ Nejat Göyünç, XVI. Yüzyılda Mardin Sancağı, İstanbul 1966, s. 18, 62-63.

134 Ebû Bakr-i Tıhranî, Kitabı Diyarbakriyya Ak-Koyunlular Tarihi, C. I, Yay. N. Lugal-F. Sümer, TTK. Yay., Ankara 1993, s. 61; Ramazan Şeşen, “İmad al-Din Al-Kâtib Al-İsfahanî'nin Eserlerindeki Anadolu Tarihiyle İlgili Bahisler", SAD, 3, Ankara 1971, s. 297.

${ }_{137}$ Osman Turan, Doğu Anadolu Türk Devletleri Tarihi, Nakıșlar Yay., İstanbul 1980, s. 115.77 nd.

138 1974 Yilı Itibariyle Yerleșim Üniteleri Kılavuzu URFA, Köy İșleri ve Kooparatifleri Başkanlığı YSE Genel Müdürlüğü, Ankara 1974, s. 7.

139) Mehmet Salih Erpolat,"XVI. Yüzyılda Siverek Sancağında İskan ve Nüfus", Tarihte Siverek Sempozyumu Bildirileri, 13-14Ekim 2001, Sanlıurfa 2002, s. 80. 
Diğer taraftan Osmanlı belgelerinde Diyarbakır'da Garb-i Amid ve Şark-ı Amid kazalarında Harzemi ${ }^{140}$, Kars-Ardahan'da Küçük Harziyan ${ }^{141}$ adlan ile birer köy bulunurken, Anadolu'ya Celâleddin Harzemşah ile gelip onun ölümünden sonra Diyarbakır-Harput bölgesinde hâkimiyetlerini 1277 yılına kadar sürdüren ve yukarıda siyasî rollerinden bahsettiğimiz Bicar ailesinin de yer adlarında izleri günümüze kadar gelmiştir. Osmanlı belgelerinde önceleri Bacer Kazası ${ }^{142}$ adıyla bir kaza hüviyetinde olan bir yerleşim birimi daha sonra köy ismi olarak Bacervan, Bacirvan, Becir Ömer, Bicar Ömer, Bacuvan, Becivan, Bicar ${ }^{143}$ gibi farklı şekillerde yazılan bir merkez köy olarak karşımıza çıkmaktadır ki bu Bicarların bu bölgedeki hatırası ile alâkalı olmalıdır.

Sonuç olarak şunu söyleyebiliriz ki, Moğol istilâsının Yakındoğu ve bilhassa Anadolu üzerindeki en önemli tesirlerinden biri, Celâleddin'den sonra ona tâbi olan Harezmlilerin Anadolu, Suriye, Irak ve Mısır siyasî olaylarında belirgin bir rol oynamış olmalarıdır. İkincisi ise, Harezmli yönetici ve emîrlerin Eyyubî, Memlûk ve Türkiye Selçukluları devletlerindeki konumları ile bilhassa Anadolu'ya dağılmış olan Harezmli toplulukların burada kalıcı bir statü ile yerleşik hayata geçmeleridir. Anadolu'nun etnik-kabilevî ve sosyo-kültürel yapısında gözle görülür tesirler meydana getiren bu Harezmli Türklerin istilâsını Harzem, Horzum, Harzunî gibi boy ve aşiret isimleri ile bu topluluk ve onların temsilcilerine ait yer adlarında gözlemlemek mümkündür. Üçüncü olarak da bütün Yakın doğu ve bilhassa Türkiye üzerinde derin tesirler bırakmış olan Moğol istilâ ve hâkimiyetinin habercisi ve âdeta bir provasını teşkil etmesidir. Ayrıca bütün bunlar XI. yüzyılın bașlarından itibaren başlayan Anadolu'nun Türkleşmesi hâdisesinin sadece siyasî ve askerî bir çerçeve içerisinde anlaşılmasının mümkün olamayacağını, bunun etnik, kabilevî, sosyal ve kültürel açıdan da ele alınması gerektiği ortaya çıkmaktadır.

${ }^{140}$ İbrahim Yılmazçelik, XIX. Yüzyılın İk Yarısında Diyarbakır(1790-1840), TTK. Yay., Ankara 1995, s. 159-160.

${ }^{141}$ Köylerimiz, T.C. İçişleri Bakanlığı İller İdaresi Genel Müdürlüğü, Ankara 1968, s. 399.

142 İ. Yilmazçelik, Diyarbakr, s. 139.

143 İ. Yulmazçelik, Diyarbakur, s. 144, 148, 151, 154, 158, 159, 163. 